\title{
P-33 DEEP-WATER MEGATURBIDITES IN THE EASTERN MEDITERRANEAN
}

M. REBESCO ${ }^{1}$, M.B. CITA², W. HIEKE ${ }^{3}$, B. DELLA VEDOVA ${ }^{4}$, G. ALOISI ${ }^{5}, F$. WERNER $^{6}$ and L. CERNOBORI ${ }^{1}$ 1 stituto Naz. di Oceanografia e di Geofisica Sperimentale, Borgo Grotta Gigante 42/C, Sgonico (TS), Italy ${ }^{2}$ Milan University

${ }^{3}$ Munchen Technical University

${ }^{4}$ Trieste University

${ }^{5}$ Pierre et Marie Curie University

${ }^{6}$ Kiel University

\section{Introduction and objectives}

The Eastern Mediterranean basin (Fig. 1) is known to contain large volume megaturbidites (homogenite of Cita and al., 1984; Augias turbidite of Hieke, 1984) produced by a catastrophic tsunami originated by the collapse of the Santorini caldera after the Bronze age (3500 y BP) eruption (Kastens and Cita, 1981; Cita et al., 1996).

Thick transparent layers identified in the acoustic records from the Ionian and Sirte Abyssal Plains and from Calabrian and Mediterranean Ridges were inferred to represent such megaturbidites. Despite the important advances in the knowledge of the depositional history of the Eastern Mediterranean, some questions are still open: (1) what are the relationships between the megaturbidites deposited on the ridges with those deposited in the abyssal plains? (2) is this a unique event in the depositional history? (3) what is the total sediment volume involved? (4) do the transparent layers represent the acoustic facies of these megaturbidites?

This study incorporate the results of four independent researches that addressed the above questions through the analyses of core data, acoustic profiles, and synthetic seismograms.

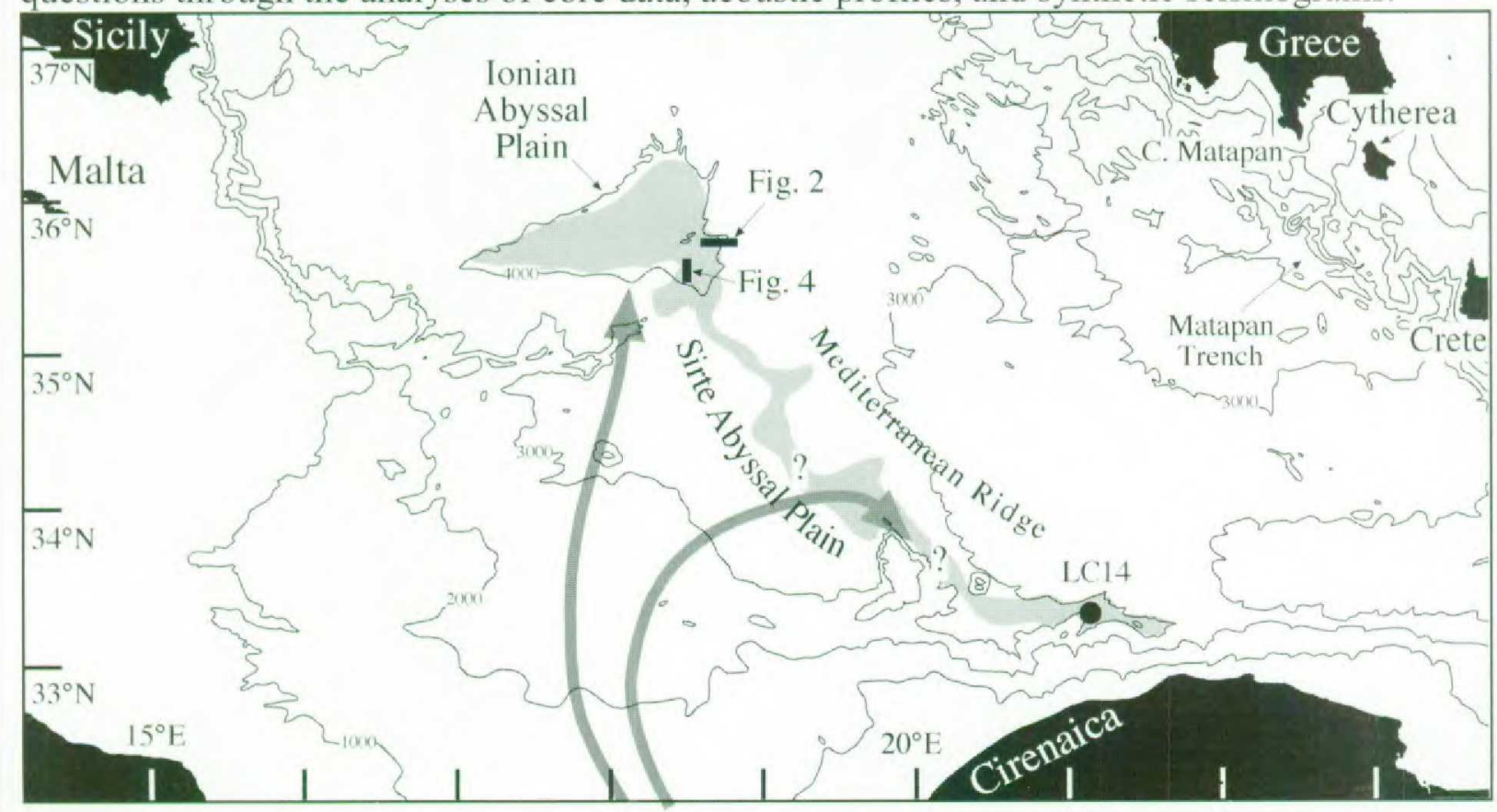

Fig. 1 Location map showing the locations of sub-bottom profiles and of Core LC14. The shaded area shows the inferred area covered by the megaturbidite. The gray arrows indicate the inferred path of turbidity current. 


\section{Methods}

Parasound echosounder records were analysed to investigate the thickness and extent of the transparent layer inferred to represent the abyssal plain megaturbidite of the Bronze age (Hieke and Werner, in press). Carbonate content and SEM analyses were also performed to investigate the source of the material (Hieke and Werner, in press).

Both parasound echosounder and single channel seismic data were analysed to investigate the presence, thickness and extent of deeper transparent layers interpreted as older megaturbidites (Hieke, in press).

Calcimetric, grain size and SEM analyses of two cores, selected from a collection of regional transects, were conducted to investigate the provenance of the megaturbidites in two different settings: plains and ridges (Cita and Aloisi, in press).

Analysis of CHIRP subbottom profiler record and comparison with synthetic seismograms were performed to investigate the acoustic facies of the Bronze age megaturbidites (Rebesco et al., in press).

\section{Results}

Two different types of megaturbidites were identified (Cita and Aloisi, in press) in two different settings (Fig. 2): pelagic turbidites of local origin deposited in small ponded basins of the Calabrian and Mediterranean ridges (Type A turbidites); and a deep sea megaturbidite, sourced from the Sirte Gulf margin, deposited in the Ionian and Sirte abyssal plains and western Herodotous Trough (Type B turbidite). Both type A and B turbidites include a structureless muddy layer and a graded sandy base, with very different thicknesses. The thick megaturbidite muddy layer has a very characteristic transparent acoustic facies, whereas the basal sand is difficult to distinguish from the underlying thin turbidites.

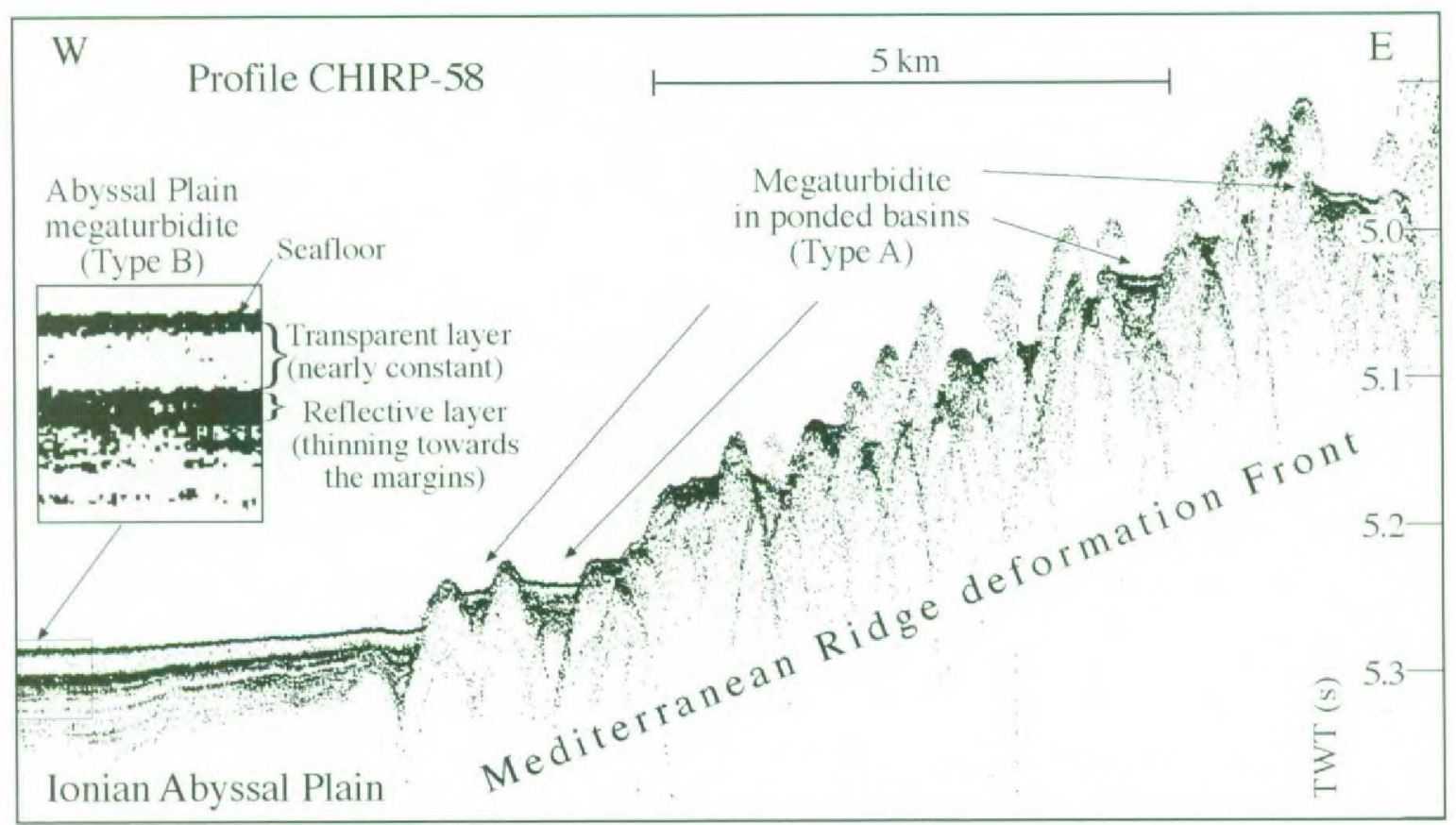

Fig. 2 CHIRP sub-bottom profile across the Mediterranean Ridge deformation front. The upper transparent acoustic layer of the megaturbidite in the abyssal plain, and in the ponded depositional basins is shown. The tendency of the reflective layer of the abyssal plain megaturbidite is to rapidly thin toward the margin of the basin. 
A minimum volume of $65 \mathrm{~km}^{3}$ for the Ionian and Sirte abyssal plain megaturbidite is calculated on the basis of the transparent layers solely (Hieke and Werner, in press).

Synthetic seismograms (Fig. 3) of a core collected in the western Herodotous Trough during Marion Dufresne Cruise 81 (Rothwell, 1995) allow to analyse the acoustic facies of the abyssal megaturbidite (Rebesco et al., in press). It consists of an upper, transparent, low velocity layer (the homogenite) and a lower, highly reflective, high velocity layer (the sandy base). This evidence suggests that the total thickness of the megaturbidite in the abyssal plains is larger than the thickness of the transparent layer identified on the acoustic profiles. The maximum estimated volume of both megaturbidite layers is hence about $115 \mathrm{~km}^{3}$ (Ionian Abyssal Plain) plus $50 \mathrm{~km}^{3}$ (Sirte Abyssal Plain and Herodotous Trough). An additional volume of $5 \mathrm{~km}^{3}$ may be added if we include the Matapan Trench.

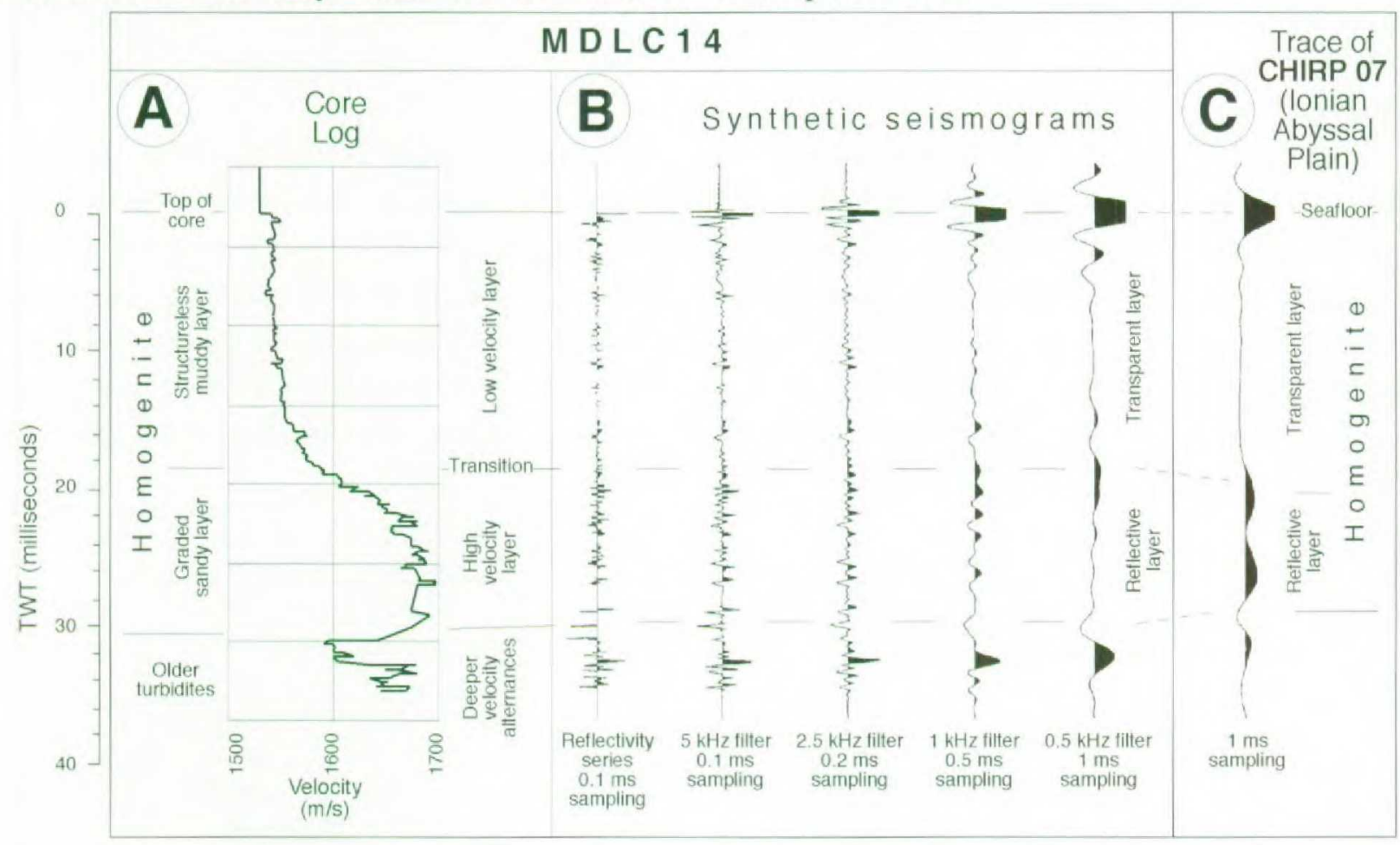

Fig. 3 (A) P-wave velocity profile of Core LC14 showing the presence of an upper, low velocity, layer, and of a lower, high velocity, layer. These layers correspond respectively to the thick structureless muddy layer, and to the thick graded sandy layer, composing the megaturbidite. (B) reflectivity series and synthetic seismograms of Core LC14. They are correlated to the velocity profile and contain an upper transparent layer and a lower reflective layer. (C) trace of sub-bottom profile Chirp 07 in the Ionian Abyssal Plain. Comparison with synthetic seismograms allows the identification of the transparent layer corresponding to the structureless mud and of the reflective layer corresponding to the graded sand.

Two pre-Holocene megaturbidites are identified in the seismostratigraphic succession (Fig. 4): the "Deeper Transparent Layer" and the "Thick Transparent Layer" (Hieke, in press). The hypotheses about their triggering mechanism are speculative and range from tsunamis and earthquakes to low-sea-level stands. 


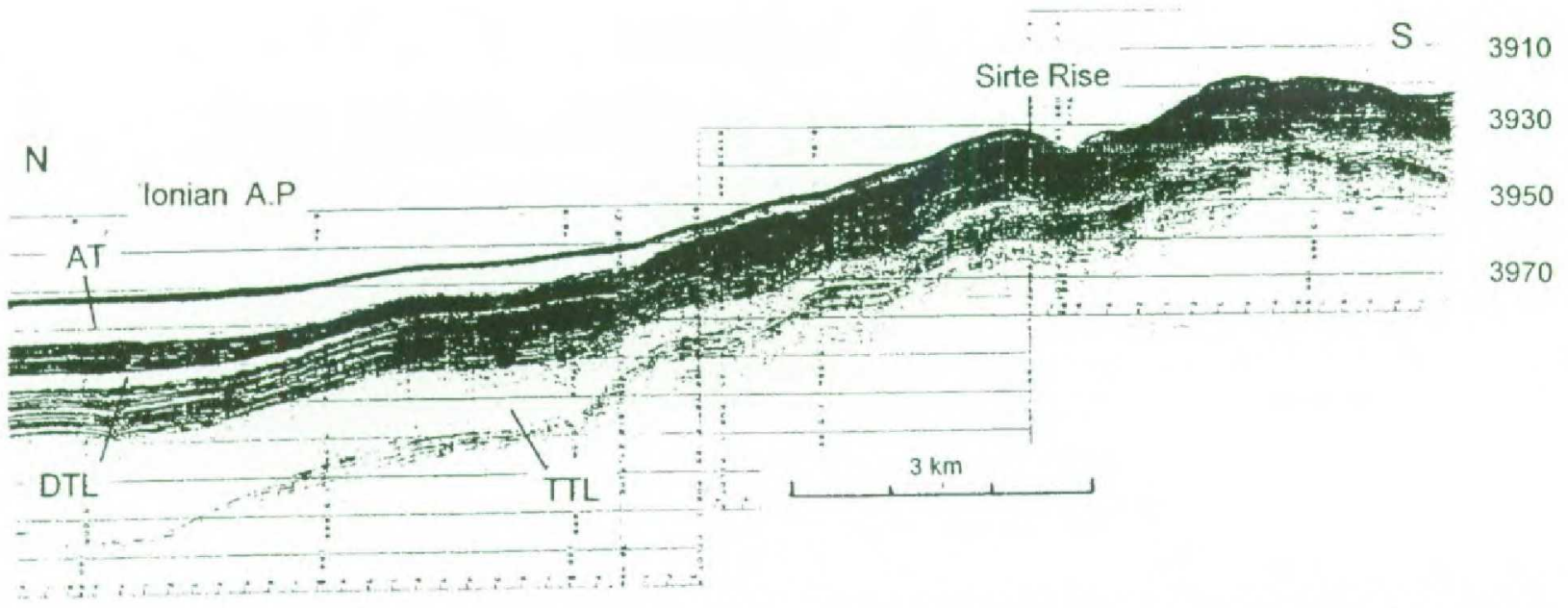

Fig. 4 Parasound echosounder record (Cruise Meteor 25, line 515) showing the Bronze age megaturbidite (AT), the "Deeper Transparent Layer" (DTL) and the "Thick Transparent Layer" (TTL).

\section{Acknowledgements}

Four independent, self-sustained researches were combined to compose this study supported by the Consiglio Nazionale delle Ricerche (CNR) and the Ministero della Ricerca Scientifica e Tecnologica (MURST) within the Seasonal, INterannual and decAdal variability of the atmosPhere, oceans and related marIne ecosystems (SINAPSI) Project.

\section{References}

Cita, M.B., and Aloisi, G., 2000. A deep-sea tsunami deposit originated by the explosion of Santorini (3500 yBP), Eastern Mediterranean. In: T. Shiki, M. Cita \& D. Gorsline (Eds), Sedimentary Features of Seismites, Seismo-turbidites and Tsunamites, Sed. Geo., 135, 1-4 (Special issue).

Cita, M.B., Camerlenghi, A. Kastens, K.A. and McCoy, F.W., 1984. New findings of Bronze Age Homogenites in the Ionian Sea: geodynamic implications for the Mediterranean. Mar. Geol., 55: 47-62.

Cita, M.B., Camerlenghi, A. and Rimoldi, B., 1996. Deep-sea tsunami deposits in the eastern Mediterranean: new evidence and depositional models. Sed. Geol., 104: 155-173.

Hieke, W., 1984. A thick Holocene homogenite from the Ionian abyssal plain (Eastern Mediterranean). Mar. Geol., 55: 63-78.

Hieke, W., 2000. Transparent layers in seismic reflection records from the central Ionian Sea (Mediterranean) evidence for repeated catastrophic turbidite sedimentation during the Quaternary. In: T. Shiki, M. Cita \& D. Gorsline (Eds), Sedimentary Features of Seismites, Seismo-turbidites and Tsunamites, Sed. Geo., 135, 1-4.

Hieke, W., and Werner, F., 2000. The Augias megaturbidite in the centrral Ionian Sea (Central Mediterranean) and its relation to the Holocene Santorini event. In: T. Shiki, M. Cita \& D. Gorsline (Eds), Sedimentary Features of Seismites, Seismo-turbidites and Tsunamites, Sed. Geo., 135, 1-4 (Special issue).

Kastens, K.A., and Cita, M.B., 1981. Tsunami-induced sediment transport in the Abyssal Mediterranean Sea. Geol. Soc. America Bull., 98: 591-604.

Rebesco M., Della Vedova B.,Cernobori L., and Aloisi G., 2000. Acoustic Facies of Holocene Megaturbidites in the Eastern Mediterranean. . In: T. Shiki, M. Cita \& D. Gorsline (Eds), Sedimentary Features of Seismites, Seismo-turbidites and Tsunamites, Sed. Geo., 135, 1-4 (Special issue), 65-74.

Rothwell, R.G., 1995. Marion Dufresne Cruise 81, Mediterranean Giant Piston Coring Transect (MAST Paleoflux Programme). Unpublished Cruise Report, Institute of Oceanographic Sciences, Godalming, Surrey, U.K. 